\title{
Monitoring the reaction mechanism in model biogas reforming by in situ transient and steady-state DRIFTS measurements
}

\author{
Luis F. Bobadilla, ${ }^{[\mathrm{a}] \star}$ Victoria Garcilaso, ${ }^{[\mathrm{a}]}$ Miguel A. Centeno, ${ }^{[\mathrm{a}]}$ and José A. Odriozola ${ }^{[\mathrm{a}]^{\star}}$
}

\begin{abstract}
In this work, the reforming of model biogas reaction has been investigated on a $\mathrm{Rh} / \mathrm{MgAl}_{2} \mathrm{O}_{4}$ catalyst. In situ transients and steady-state DRIFTS measurements were used to gain insights about the reaction mechanism involved in the activation of $\mathrm{CH}_{4}$ and $\mathrm{CO}_{2}$. It was found that the reaction proceeds through of an initial pathway in which methane and $\mathrm{CO}_{2}$ are both dissociated on $\mathrm{Rh}$ metallic sites, and additionally a bifunctional mechanism in which methane is activated on $\mathrm{Rh}$ sites and $\mathrm{CO}_{2}$ is activated on the basic sites of the support surface via formate intermediate by $\mathrm{H}$-assisted $\mathrm{CO}_{2}$ decomposition. Moreover, this plausible mechanism is able to explain why the observed apparent activation energy of $\mathrm{CO}_{2}$ was much lower than that of $\mathrm{CH}_{4}$. Our results suggest that the $\mathrm{CO}_{2}$ dissociation facilitates the $\mathrm{CH}_{4}$ activation because the oxygen adsorbed species formed in the decomposition of $\mathrm{CO}_{2}$ are capable to react with the $\mathrm{CH}_{\mathrm{x}}$ species derived from the methane decomposition.
\end{abstract}

\section{Introduction}

A key element to achieve a sustainable development is introducing renewable energy in the chemical production chain to reduce the impact on environment and greenhouse gas (GHG) emissions. The use of biomass (particularly waste) and reuse of $\mathrm{CO}_{2}$ are two key elements enabling a new scenario for the chemical production ${ }^{[1]}$. Biogas generated by anaerobic digestion processes from the organic wastes is considered as one of the important bio-renewable resources for the next generation. The composition of biogas varies depending on the fermentation process and the feedstock, although the major constituents are methane (60\%) and carbon dioxide (40\%) with trace amounts of other gases ${ }^{[2]}$. Biogas reforming have received a great attention due to its environmental benefits from utilizing these two greenhouse gases and producing highly valuable synthesis gas (syngas, $\mathrm{H}_{2}$ and $\mathrm{CO}$ ) as a feedstock ${ }^{[3]}$. Syngas can be used as a raw material for the production of synthetic fuels with low environmental impact such as hydrogen, methanol, dimethylether (DME) and higher hydrocarbons ${ }^{[4]}$.

Since model biogas is composed essentially by methane and carbon dioxide, the dry reforming of methane (DRM) is one of

[a] Dr. L.F.Bobadilla, V. Garcilaso, Dr. M.A. Centeno,

Prof. J.A. Odriozola

Instituto de Ciencia de Materiales de Sevilla

Centro Mixto Universidad de Sevilla-CSIC

49 Av. Américo Vespucio, 41092 Sevilla (Spain)

E-mail: bobadilla@icmse.csic.es (Luis F. Bobadilla) odrio@us.es (José A. Odriozola)

Supporting information for this article is given via a link at the end of the document the more interesting reaction than can be applied to produce syngas:

DRM: $\mathrm{CH}_{4}+\mathrm{CO}_{2} \rightarrow 2 \mathrm{CO}+2 \mathrm{H}_{2} \quad \Delta \mathrm{H}=247 \mathrm{~kJ} \mathrm{~mol}^{-1} \quad$ (Eqn. 1)

Several studies summarized in different reviews have showed the high efficiency of supported transition metals in this reaction ${ }^{[5]}$. Noble metals such as $\mathrm{Rh}, \mathrm{Ru}, \mathrm{Pt}, \mathrm{Pd}$ and $\mathrm{Ir}$ are generally very active for DRM, without significant coke formation, due to small equilibrium constants for methane decomposition and low dissolution of carbon into their lattices ${ }^{[6]}$. Rh appears to be one of the most active and stable metals to catalyse $\mathrm{CO}_{2}$ reforming of $\mathrm{CH}_{4}{ }^{[7]}$. It is generally accepted that the dissociative adsorption of both $\mathrm{CH}_{4}$ and $\mathrm{CO}_{2}$ on the metallic sites of the catalysts depend on both electronic and geometric factors. Evidence has been provided to indicate that differences in activity for DRM over a given metal dispersed on different supports may be due to metal-support interactions and/or the participation of $\mathrm{O}$ or $\mathrm{OH}$ species from the support in the metalsupport interfacial region ${ }^{[5 b]}$. As the adsorptive dissociation of methane, occurring on the metal surface, is one of the ratelimiting steps, the support must offer a high metal dispersion. Moreover, the support must provide the active sites for the adsorption and dissociation of $\mathrm{CO}_{2}$. Wang and Ruckenstein ${ }^{[7 \mathrm{~b}]}$ reported that reforming rates on Rh-supported catalysts depend on the reducibility of the supports. Methane conversion on $\mathrm{Rh}$ supported non-reducible oxides $\left(\mathrm{Al}_{2} \mathrm{O}_{3}, \mathrm{SiO}_{2}, \mathrm{MgO}, \mathrm{Y}_{2} \mathrm{O}_{3}, \mathrm{La}_{2} \mathrm{O}_{3}\right)$ is higher than on reducible ones $\left(\mathrm{CeO}_{2}, \mathrm{TiO}_{2}\right)$. They concluded that $\mathrm{MgO}$ and $\mathrm{Al}_{2} \mathrm{O}_{3}$ are the most promising supports for $\mathrm{CO}_{2}$ reforming of methane. On the other hand, it is well known that increased Lewis basicity of the support leads to increased adsorption of $\mathrm{CO}_{2}$ which produces surface species able to react with carbon to form $\mathrm{CO}$. For instance, it has been reported that the addition of $\mathrm{MgO}$ enhances the catalytic performance of alumina based catalysts as an effective promoter ${ }^{[8]}$.

During the last decades, numerous studies have been devoted to understand the reaction mechanism and elementary steps at the atomic level of $\mathrm{CO}_{2}$ dry reforming over noble metal supported catalysts ${ }^{[5 a]}$. However, the nature of the adsorbed species involved in the process as well as the key intermediates remain still under debate. In order to know what exactly is occurring on the catalyst surface during the reaction it is necessary to combine the direct observation by spectroscopic techniques with the computational modelling methods. Recently, Polo-Garzón et al. have reported a complete mechanistic study employing ab initio methods [9] and steady-state isotopic transient kinetic analysis (SSITKA) ${ }^{[10]}$ to gain insights into the dry reforming of methane reaction on Rh-substituted lanthanum zirconate pyrochlore catalyst. Combining both experimental and theoretical studies, they found that the main reaction pathway consists in the dehydrogenation of adsorbed methane to 
generate $\mathrm{CH}_{2}$ species, which then are oxygenated to $\mathrm{CH}_{2} \mathrm{O}$ species by atomic oxygen from $\mathrm{CO}_{2}$ dissociation. $\mathrm{CH}_{2} \mathrm{O}$ dehydrogenates to create $\mathrm{CHO}$ species, which undergoes dissociation to release a hydrogen atom and an adsorbed $\mathrm{CO}$ that later desorbs to yield product gas. These adsorbed hydrogens can also interact with surface bound species derived from $\mathrm{CO}_{2}$ to yield additional $\mathrm{CO}$ product and water via the reverse water gas shift (RWGS) reaction. Erdöhelyi et al. ${ }^{[7 c]}$ investigated the $\mathrm{CH}_{4}$ and $\mathrm{CO}_{2}$ dissociation as well as the reforming reaction of $\mathrm{CH}_{4}$ with $\mathrm{CO}_{2}$ over $\mathrm{Rh} / \mathrm{Al}_{2} \mathrm{O}_{3}$ by means of FTIR and kinetic measurements. They suggested that the $\mathrm{CO}_{2}$ dissociation is promoted by the presence of methane. The products distribution depended strongly on the surface coverage by oxygen and carbon deposits.

In-situ transient diffuse reflectance infrared Fourier transform spectroscopy (DRIFTS) has been widely employed as a useful tool to elucidate the mechanism and uncover the role of the involved species during the reaction. However, the kinetic responses of the surface species analysed under transient conditions could be characteristically distinct from those measured from steady-state experiments. On the other hand, steady-state rate measurements cannot provide direct information about the nature and coverage of surface intermediates. Therefore, it would be desirable to integrate both transient and steady-state in situ approaches to gain a more comprehensive and definitive vision of the investigated catalytic reaction. A good understanding of the reaction mechanism will provide useful guidance to achieve an optimal catalyst in terms of activity, selectivity and durability. The present contribution deals with a comprehensive study to clarify some aspects of the activity of a Mg-promoted $\mathrm{Rh} / \mathrm{Al}_{2} \mathrm{O}_{3}$ catalyst toward biogas reforming reaction and understand the mechanism using transient and steady-state DRIFTS experiments.

\section{Results and Discussion}

The activity of $\mathrm{Rh}$ supported on $\mathrm{MgAl}_{2} \mathrm{O}_{4}$ catalyst was measured under continuous flow-conditions at atmospheric pressure using a $\mathrm{CH}_{4} / \mathrm{CO}_{2}$ molar ratio equal to 1.5 . Figure 1 depicts the influence of reaction temperature on $\mathrm{CH}_{4}$ and $\mathrm{CO}_{2}$ conversion, and on the $\mathrm{H}_{2} / \mathrm{CO}$ molar ratio. It can be observed that both $\mathrm{CH}_{4}$ and $\mathrm{CO}_{2}$ conversion values increase with the temperature, in accordance with the strong endothermic character of the reaction. As $\mathrm{CO}_{2}$ is the limiting reactant, it is expected that $\mathrm{CH}_{4}$ conversion exhibit lower values for the whole temperature range compared to $\mathrm{CO}_{2}$. The high conversion of $\mathrm{CH}_{4}$ observed at higher temperatures could be ascribed to the methane decomposition reaction, as the predominant reaction to form hydrogen and carbon:

$\mathrm{CH}_{4}$ decomposition: $\mathrm{CH}_{4} \leftrightarrow \mathrm{C}+\mathrm{H}_{2} \quad \Delta \mathrm{H}=75 \mathrm{~kJ} \mathrm{~mol}^{-1}$

(Eqn. 2)

Furthermore, this reaction could be favored by the secondary reaction of reverse water gas shift (RWGS), where the hydrogen produced is consumed in the reaction with $\mathrm{CO}_{2}$ in agreement with results obtained by Parkhomenko et al. ${ }^{[11]}$.

RWGS: $\mathrm{CO}_{2}+\mathrm{H}_{2} \leftrightarrow \mathrm{CO}+\mathrm{H}_{2} \mathrm{O} \quad \Delta \mathrm{H}=41 \mathrm{~kJ} \mathrm{~mol}^{-1}$

On the other hand, it is noticeable that the $\mathrm{H}_{2} / \mathrm{CO}$ molar ratio values obtained increase with the increment of temperature and it becomes slightly greater than the stoichiometric value of 1 at $750 \stackrel{\circ}{ } \mathrm{C}$. This fact could be explained by the dominance of the cracking reaction of $\mathrm{CH}_{4}$ to form $\mathrm{H}_{2}$ and carbon at higher temperatures. Moreover, according to thermodynamic equilibrium, for $\mathrm{CH}_{4} / \mathrm{CO}_{2}$ molar ratios superior to 1 , the amount of $\mathrm{H}_{2}$ produced increases with the temperature since $\mathrm{CO}_{2}$ is the limiting reactant and the RWGS reaction cannot simultaneously improve along with the dry reforming reaction ${ }^{[12]}$.

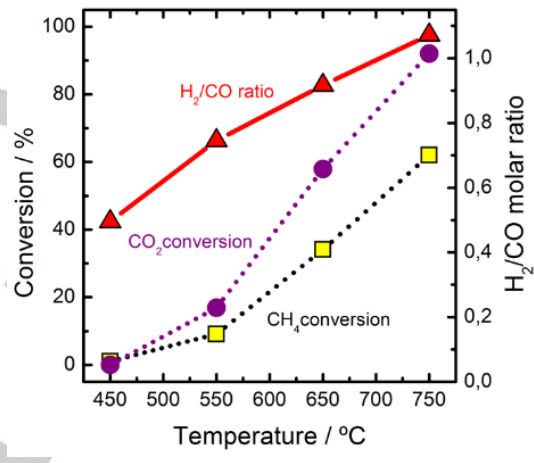

Figure 1. Effect of reaction temperature on the conversions of $\mathrm{CO}_{2}$ and $\mathrm{CH}_{4}$ and the molar ratio of $\mathrm{H}_{2} / \mathrm{CO}$ over $\mathrm{Rh} / \mathrm{MgAl}_{2} \mathrm{O}_{4}$ catalyst. Reaction conditions: WHSV $=150 \mathrm{~L} \mathrm{~g}^{-1} \mathrm{~h}^{-1}, \mathrm{CH}_{4} / \mathrm{CO}_{2}=1.5$ and 1 bar

The results of catalytic activity presented in this study are in accordance with the thermodynamic model predicted by Nikoos et al. ${ }^{[13]}$. They reported that for $\mathrm{CH}_{4} / \mathrm{CO}_{2}$ molar ratio equal to 1.5 , the methane decomposition reaction is considered to be the main reaction forming $\mathrm{H}_{2}$ and carbon at higher temperatures.

In situ transient experiments were performed using two different combinations of reactants in order to observe the gas phase reactants and products and to identify the surface species present on the $\mathrm{Rh} / \mathrm{MgAl}_{2} \mathrm{O}_{4}$ catalyst. We have examined the formation of surface species from gas streams containing $\mathrm{CO}_{2}$ or $\mathrm{H}_{2}+\mathrm{CO}_{2}$ at $600^{\circ} \mathrm{C}$, and subsequently, we have monitored the evolution of the formed species by switching a gas stream containing $\mathrm{CH}_{4}$ every $560 \mathrm{~s}$. Noteworthy that in this study we do not aim to identify which surface species are involved in $\mathrm{H}_{2}$ production but rather to investigate the mechanism of $\mathrm{CO}_{2}$ and $\mathrm{CH}_{4}$ dissociation using DRIFTS as one of the most sensitive techniques for following the interaction of $\mathrm{CO}_{2}$ and/or $\mathrm{CH}_{4}$ with the catalyst. This type of experiment enables direct correlation of specific surface species with the production of gaseous products.

A series of IR spectra recorded during alternate switching between $\mathrm{CO}_{2}$ and $\mathrm{CH}_{4}$ feeds are presented in Fig.2A. The IR features obtained during $\mathrm{CO}_{2}$ exposure show that adsorption of $\mathrm{CO}_{2}$ at $600{ }^{\circ} \mathrm{C}$ leads to the formation of metallic carbonyls and $\mathrm{CO}$ adsorbed species as well as to $\mathrm{CO}$ gas-phase. This fact 
reveals that $\mathrm{CO}_{2}$ adsorption dissociative takes place on the surface catalyst and more concretely on the metallic active sites. In addition, the rhodium-based catalyst presents several bands in the range $1350-1650 \mathrm{~cm}^{-1}$ that can be ascribed to carbonate species. It is generally accepted that $\mathrm{CO}_{2}$ chemisorption and dissociation on a transition metal surface is dominated by electron transfer and requires the formation of a carbonate precursor ${ }^{[14]}$. When $\mathrm{CO}_{2}$ stream was switched by $\mathrm{CH}_{4}$ stream, the IR bands attributed to carbonates species almost disappeared completely while that the intensities of the bands attributed to $\mathrm{CO}$ adsorbed and metallic carbonyls were only partially decreased.

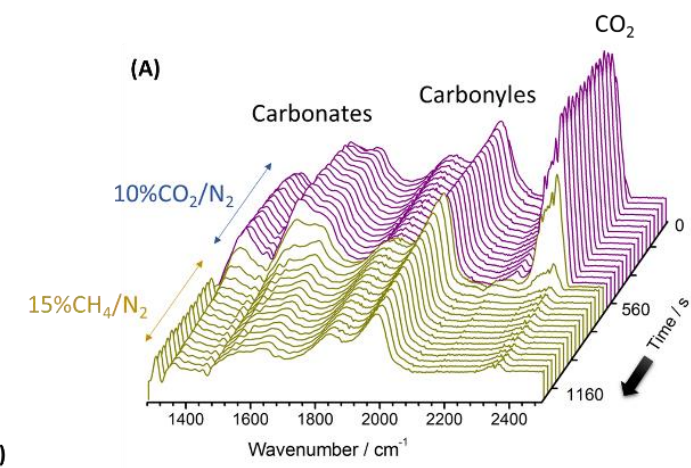

(C)

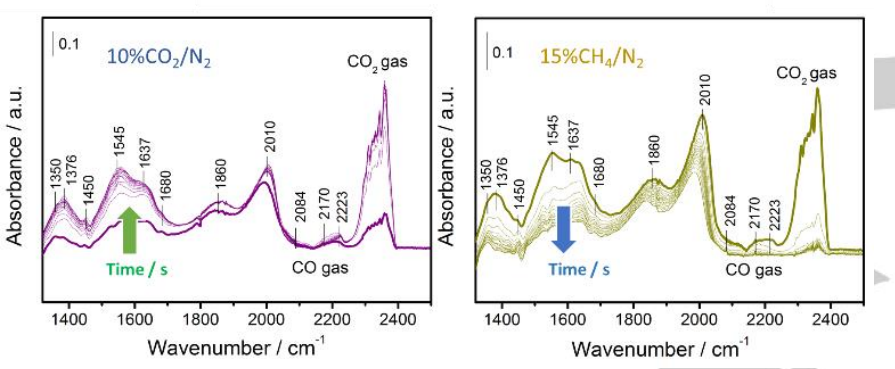

Figure 2. DRIFT spectra collected at $650^{\circ} \mathrm{C}$ when the feed gas was switched from $\mathrm{CO}_{2} / \mathrm{N}_{2}$ to $\mathrm{CH}_{4} / \mathrm{N}_{2}$ over $\mathrm{Rh} / \mathrm{MgAl}_{2} \mathrm{O}_{4}$ catalyst.

The temporal evolution of the bands attributed to the different species can be seen more clearly in Fig. $2 \mathrm{~B}$ and Fig. 2C. The bands appearing at 1450-1680, 1376-1545 and 1350-1637 $\mathrm{cm}^{-1}$ can be assigned to three types of carbonates surface adsorbed species on the Rh supported catalyst: bicarbonate, monodentate and bidentate carbonates, respectively ${ }^{[15]}$. The different $\mathrm{CO}_{2}$ adsorption modes depend on the chemical nature of the surface oxygen atoms. The chemisorption of $\mathrm{CO}_{2}$ reveals acidic sites where the $\mathrm{CO}_{2}$ molecule preserves its linear geometry upon adsorption, and basic sites as well as acid-base pairs when carbonate-likes species are formed [15a]. Monodentate carbonates formation involves low-coordination or isolated surface $\mathrm{O}_{2}^{-}$anions such as those present in corners or edges, bidentate carbonate forms on Lewis-acid-base pairs $\left(\mathrm{M}-\mathrm{O}_{2}^{-}\right.$pair site, where $\mathrm{M}$ is the metal cation $\mathrm{Mg}$ or $\mathrm{Al}$ ), and bicarbonate formation involves surface hydroxyl groups ${ }^{[15 d, 16]}$. CO adsorbed on Rh-based catalysts has been widely investigated and different CO species can be present. The IR bands at 2010 and $1860 \mathrm{~cm}^{-1}$ can be attributed to linear and bridged adsorbed CO species on Rh metallic sites, respectively ${ }^{[17]}$. There is also a weaker feature at $2084 \mathrm{~cm}^{-1}$ that can be assigned to a germinal (gem-) dicarbonyl species ${ }^{[18]}$. The presence of gem-dicarbonyl species is associated to de the oxidation of $\mathrm{Rh}^{0}$ to $\mathrm{Rh}^{+}$cations due to the presence of hydroxyl groups on the support surface according to ${ }^{[19]}$ :

$2 \mathrm{Rh}+4 \mathrm{CO}+2 \mathrm{Al}(\mathrm{Mg}) \mathrm{OH} \rightarrow \mathrm{H}_{2}+2 \mathrm{Al}(\mathrm{Mg})-\mathrm{O}-\mathrm{Rh}(\mathrm{CO})_{2}$

(Eqn. 4)

This oxidation disrupts the Rh-Rh bonds generating the gemdicarbonyl species and provoking a redispersion of the $\mathrm{Rh}$ particles ${ }^{[20]}$. Thus, the detection of gem-dicarbonyl complexes is considered significant for the existence of highly dispersed $\mathrm{Rh}$ metal particles on the catalyst surface. Apart from this, it is noticeable a broad feature in the $2100-2250 \mathrm{~cm}^{-1}$ region which correspond to $\mathrm{CO}$ gas (inside the cell) and two weak peaks at 2170 and $2223 \mathrm{~cm}^{-1}$ that can be assigned to $\mathrm{CO}$ adsorbed to low coordinated $\mathrm{Al}^{3+}$ ions on the $\mathrm{MgAl}_{2} \mathrm{O}_{4}$ spinel structure and alumina support, respectively ${ }^{[21]}$.

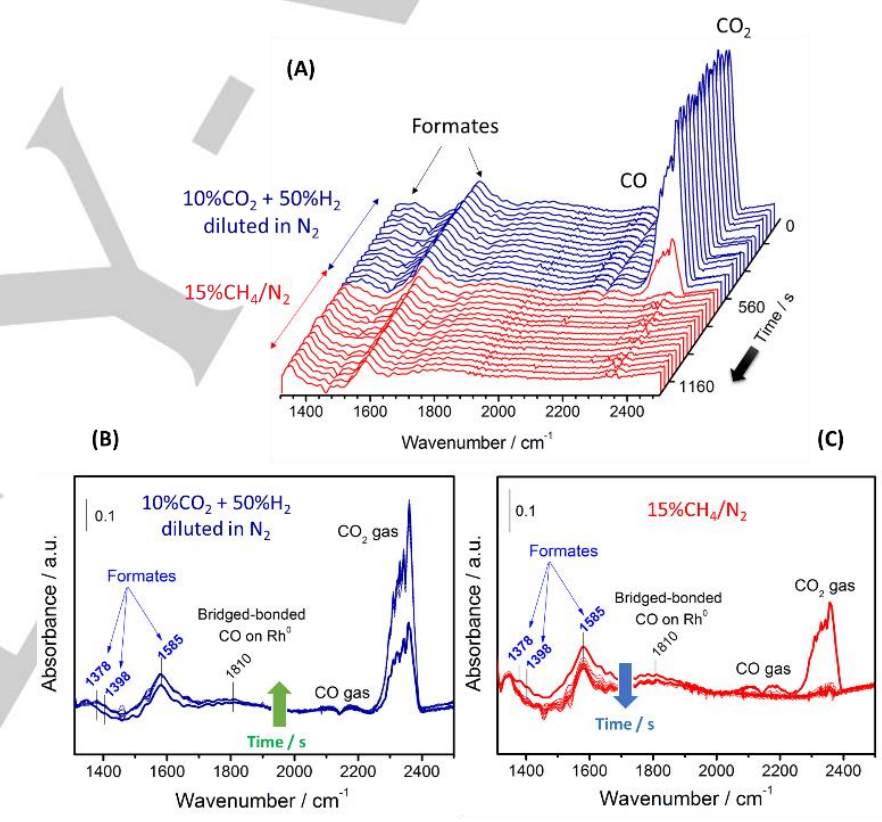

Figure 3. DRIFT spectra collected at $650^{\circ} \mathrm{C}$ when the feed gas was switched from $\left(\mathrm{CO}_{2}+\mathrm{H}_{2}\right) / \mathrm{N}_{2}$ to $\mathrm{CH}_{4} / \mathrm{N}_{2}$ over $\mathrm{Rh} / \mathrm{MgAl}_{2} \mathrm{O}_{4}$ catalyst.

A series of spectra reported in Fig. 3A shows the evolution of the surface species formed on the $\mathrm{Rh} / \mathrm{MgAl}_{2} \mathrm{O}_{4}$ catalyst during alternate switching between $\mathrm{CO}_{2}+\mathrm{H}_{2}\left(1: 4\right.$ molar ratio) and $\mathrm{CH}_{4}$ only feeds. During the $\mathrm{CO}_{2}+\mathrm{H}_{2}$ introduction, compared with the $\mathrm{CO}_{2}$ exposure (Fig. 2A), the appearance of new IR features at 1580,1398 and $1378 \mathrm{~cm}^{-1}$ as well as a low intense band at 2915 $\mathrm{cm}^{-1}$ (not shown) indicates the presence of adsorbed formate species on the catalyst surface. Moreover, the formation of gasphase $C O$ reveals that RWGS reaction takes place. As has been claimed in the literature, it is assumed that the formation of $\mathrm{CO}$ proceeds via decomposition of formate species as intermediates in the RWGS reaction. On the other hand, it can be also observed the presence of CO-bridged adsorbed species. The 
CO produced by RWGS reaction can interact with the Rh particles forming CO linear, CO bridged and/or gem-dicarbonyl species. The only presence of CO-bridged species suggests their inactivity and its possible role as spectator during the reaction.

Figure 4 illustrates the concentration profiles of $\mathrm{CO}_{2}$ and $\mathrm{CH}_{4}$ during the modulation of both combination of reactants, $\mathrm{CO}_{2}$ vs $\mathrm{CH}_{4}$ and $\mathrm{CO}_{2}+\mathrm{H}_{2}$ vs $\mathrm{CH}_{4}$, for a period of 3 modulation cycles. As can be noticed, when only $\mathrm{CO}_{2}$ was exposure the concentration of $\mathrm{CO}_{2}$ was gradually increased until the $\mathrm{CO}_{2}$ saturation level was reached. According to the DRIFTS results discussed above (Figure 2), it is evident that $\mathrm{CO}_{2}$ is dissociated to $\mathrm{CO}$ and oxygen active species during an initial transient or induction period where the metallic surface particles become entirely covered of CO-adsorbed species and at the same time $\mathrm{CO}_{2}$ is trapped over the surface support on the basic adsorption sites expectedly in the form of surface carbonates. Subsequently, by switching the gas feed from $\mathrm{CO}_{2}$ to $\mathrm{CH}_{4}$, the oxygen active species on metallic sites favored the $\mathrm{CH}_{4}$ decomposition to $\mathrm{H}_{2}$ and $\mathrm{CH}_{\mathrm{x}}$ species and the concentration of methane delays a few of seconds to achieve the saturation level. On the other hand, during the $\mathrm{CO}_{2}+\mathrm{H}_{2}$ mixture feed, one may notice that the level of $\mathrm{CO}_{2}$ in the effluent was always below the saturation level reveling a continuous formation of $\mathrm{CO}$ via RWGS reaction. As the gas stream was switched to methane, the level of methane directly reached the saturation without the ongoing increase during the initial several seconds. This reveals the absence of active oxygen species capable to activate the $\mathrm{CH}_{4}$ dissociation since in presence of hydrogen predominates the $\mathrm{H}$-assisted $\mathrm{CO}_{2}$ dissociation to produce CO via formate intermediates.

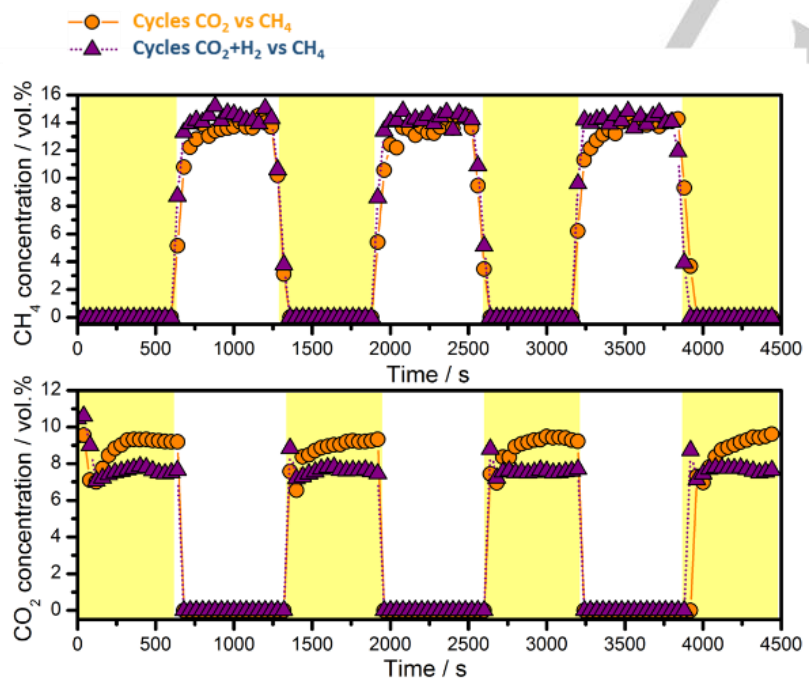

Figure 4. $\mathrm{CH}_{4}$ and $\mathrm{CO}_{2}$ concentration profiles as a function of time when the feed gas was switched from $\mathrm{H}_{2} / \mathrm{N}_{2}$ or $\left(\mathrm{CO}_{2}+\mathrm{H}_{2}\right) / \mathrm{N}_{2}$ to $\mathrm{CH}_{4} / \mathrm{N}_{2}$ over $\mathrm{Rh} / \mathrm{MgAl}_{2} \mathrm{O}_{4}$ catalyst at $650^{\circ} \mathrm{C}$

On the basis of the above understanding, two possibilities could be considered for the production of $\mathrm{CO}$ : i) direct dissociation of $\mathrm{CO}_{2}$ on $\mathrm{Rh}$ metallic particles in absence of hydrogen, and ii) $\mathrm{H}$-assisted $\mathrm{CO}_{2}$ reduction by dehydroxylation of intermediate formate species formed on the support. Concerning to the former possibility, we have observed that carbon dioxide dissociation is achieved in absence of hydrogen and a large amount of $\mathrm{CO}$ adsorbed species on $\mathrm{Rh}$ is produced. By contrast, the $\mathrm{H}$-assisted carbon monoxide formation can be assumed to occur through an activated formate-type intermediates, which accounts for the amount of formate species on the catalyst surface.

In absence of hydrogen, our data show the activation of $\mathrm{CO}_{2}$ on Rh catalyst occur via direct dissociation to $\mathrm{CO}$ adsorbed and $O$. When methane is introduced, the adsorbed oxygen facilitates the dissociation of methane by reaction with the $\mathrm{CH}_{\mathrm{x}}$ formed on the catalyst surface. In opposite, the $\mathrm{H}$-assisted activation of $\mathrm{CO}_{2}$ produces formate species adsorbed that decompose to $\mathrm{CO}$ and $\mathrm{H}_{2} \mathrm{O}$. The absence of active oxygen species on the metal surface in this case enables the activation of methane and only RWGS reaction is possible. Thus, one can conclude that the $\mathrm{CO}_{2}$ dissociation results in the covering of the metallic sites with adsorbed active oxygen species which favors the methane dissociation

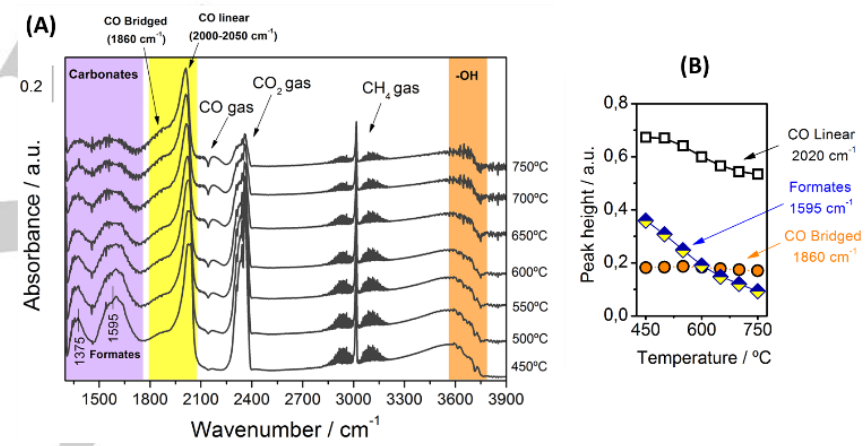

Figure 5. (A) DRIFT spectra obtained during $\mathrm{CO}_{2}$ reforming of methane in the temperature range from 450 to $750^{\circ} \mathrm{C}$. (B) Evolution of the peak height attributed to CO-linear, CO-bridged and formate surface species as a function of the reaction temperature. Reaction conditions: 1 bar, total flow rate of $50 \mathrm{~mL}$ $\mathrm{min}^{-1}$ and $\mathrm{CH}_{4} / \mathrm{CO}_{2}=1.5$ (molar ratio)

In situ DRIFTS spectroscopy was used to study the chemical nature of intermediate species formed during the biogas reforming reaction in the temperature range of $450-750 \stackrel{\circ}{ } \mathrm{C}$ on the $\mathrm{Rh} / \mathrm{MgAl}_{2} \mathrm{O}_{4}$ catalyst. Figure $5 \mathrm{~A}$ shows the DRIFTS spectra recorded under steady-state conditions for the $\mathrm{Rh} / \mathrm{MgAl}_{2} \mathrm{O}_{4}$ catalyst after stabilization under the reaction mixture at the indicated temperature. The spectra recorded at every temperature present intense bands ascribed to absorbed carbonyls with peaks around 1860 and in the range 2000-2050 $\mathrm{cm}^{-1}$ range corresponding to linear and bridged carbonyls on metallic rhodium, respectively, while the IR bands in the 1300$1650 \mathrm{~cm}^{-1}$ range signify carbonate species ${ }^{[15 a]}$. Furthermore, it can be appreciated the presence of intense bands at 1590-1375 $\mathrm{cm}^{-1}$ corresponding to formates ${ }^{[15 b]}$. Fig. $5 \mathrm{~B}$ reports a plot of the height peaks associated with surface formates $\left(1595 \mathrm{~cm}^{-1}\right)$, CObridged $\left(1860 \mathrm{~cm}^{-1}\right)$ and CO-linear $\left(2020 \mathrm{~cm}^{-1}\right)$ as a function of the reaction temperature. As can be observed, by increasing the reaction temperature the amount of formate species is notably 
decreased while that of linearly adsorbed $\mathrm{CO}$ species are slightly decreased and the content of bridged carbonyls remains unaltered. This suggest that the bridged adsorbed $\mathrm{CO}$ species are spectator during the reaction. It can be understood considering that the $\mathrm{Rh}-\mathrm{CO}$ bonding in bridged carbonyls is much more stable and stronger than in linear carbonyls and gem-dicarbonyls.

The turnover frequency (TOF) can be defined as the number of product molecules produced or the number of reactant molecules transformed per catalyst site and per unit time. The most common manner to determine the TOF is from the relationship between the reaction rate and the surface metal exposed. The calculation of TOF is complicated since it is impossible to know exactly the real number of accessible active sites under reaction conditions. Moreover, it depends on whether the reaction is structure-sensitive or structureinsensitive. Thus, the quantification of the exact number of surface sites exposed requires an approximation ${ }^{[22]}$. Although it is well known that both the methane activation and the dissociation of $\mathrm{CO}_{2}$ are structure sensitive and promoted at defect sites such as edges and corners ${ }^{[5 b]}$, we have assumed that all the surface atoms of Rh exposed are active sites in the main reaction pathway. We suppose that if they are not all equally active, the turnover rate will have an average value. Accordingly, the TOF was calculated by using the following equation ${ }^{[23]}$ :

$$
T O F=\frac{r \cdot M_{R h}}{D_{R h}}\left[s^{-1}\right]
$$

where $r$ is the reaction rate expressed in mol reactant converted mol $_{\mathrm{Rh}}{ }^{-1}$ $\mathrm{s}^{-1}, \mathrm{M}_{\mathrm{Rh}}$ is the atomic weight of rhodium $\left(102.9 \mathrm{~g} \mathrm{~mol}^{-1}\right)$ and $D_{\mathrm{Rh}}$ is the metal dispersion. In all cases, rhodium dispersion was estimated to be $85 \%$ on the basis of the cuboctahedral particles model proposed by Polisset ${ }^{[24]}$ and assuming an average $\mathrm{Rh}$ particle size of $1 \mathrm{~nm}$ obtained by TEM measurements (Fig. S2 in Supporting Information). The reaction rates of $\mathrm{CO}_{2}$ and $\mathrm{CH}_{4}$ converted were estimated from the data analysis of gas-phase in the DRIFTS cell.

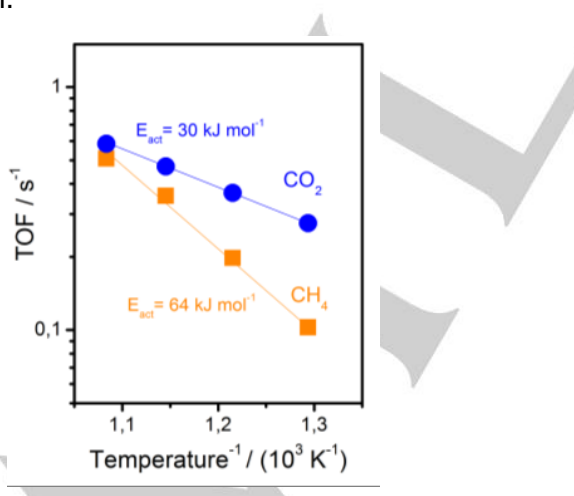

Figure 6. Turnover frequencies (TOFs) of $\mathrm{CO}_{2}$ and $\mathrm{CH}_{4}$ consumption as a function of reciprocal temperature expressed in Kelvin units on $\mathrm{Rh} / \mathrm{MgAl} \mathrm{O}_{4}$ obtained in the DRIFTS cell. Reaction conditions: 1 bar, total flow rate of 50 $\mathrm{mL} \min ^{-1}$ and $\mathrm{CH}_{4} / \mathrm{CO}_{2}=1.5$ (molar ratio).
Figure 6 shows the $\mathrm{CH}_{4}$ and $\mathrm{CO}_{2}$ turnover rates (TOFs) plotted against reciprocal temperature expressed in Kelvin units in order to estimate the apparent activation energy. As can be observed, the apparent activation energy of $\mathrm{CO}_{2}$ consumption $\left(30 \mathrm{~kJ} \mathrm{~mol}^{-1}\right)$ was much lower than that of $\mathrm{CH}_{4}$ one $\left(64 \mathrm{~kJ} \mathrm{~mol}^{-1}\right)$. Similar values of activation energy for $\mathrm{CH}_{4}$ and $\mathrm{CO}_{2}$ were obtained by Zhang et al. ${ }^{[25]}$ using a bimetallic $\mathrm{Ni}-\mathrm{Co} / \mathrm{Mg}(\mathrm{Al}) \mathrm{O}$ catalyst. This points to the important influence of the support in the reaction and likely this notably difference between activation energies of $\mathrm{CO}_{2}$ and $\mathrm{CH}_{4}$ was due to the presence of strong Lewis basic sites on $\mathrm{MgAl}_{2} \mathrm{O}_{4}$ spinel, which facilitates the $\mathrm{CO}_{2}$ activation. On the other hand, the presence of formate species observed by in situ DRIFTS indicates that RWGS reaction plays a major role in the $\mathrm{CO}_{2}$ activation and the support has an important influence in the reaction mechanism. This observation is in agreement with the results reported by Nagaoka et al. ${ }^{[6]}$ for Pt-based catalysts, where the activation energy for the rate of $\mathrm{CH}_{4}$ and $\mathrm{CO}_{2}$ disappearance varies for different supports. The majority of values reported in the literature using different noble metals as active phase shows that the activation energy for methane is greater than the one estimated for $\mathrm{CO}_{2}$. This is consistent with other reactions involving methane and it is mainly due to the high energy required to activate the stable $\mathrm{C}-\mathrm{H}$ bond on methane.

Most of the reaction mechanism reported in the literature for the $\mathrm{CO}_{2}$ reforming of methane reaction are based on the Langmuir-Hinshelwood model. It involves a dissociative adsorption of the reactants $\left(\mathrm{CH}_{4}\right.$ and $\left.\mathrm{CO}_{2}\right)$ followed by ratedetermining surface reaction of the adsorbed species to the final products ${ }^{[27]}$. Based on the results obtained in this work and the reaction mechanisms postulated in the literature, the following elementary reaction steps seem appropriated to describe the mechanism involved in the biogas reforming reaction:

1) $\mathrm{CO}_{2}(\mathbf{g}) \leftrightarrow \mathrm{CO}^{*}+\mathrm{O}^{*} \quad \mathrm{CO}_{2}$ direct dissociation

2) $\mathrm{CH}_{4}(\mathbf{g}) \leftrightarrow \mathrm{CH}_{3}{ }^{*}+\mathrm{H}^{*} \quad \mathrm{CH}_{4}$ dissociation on metal

3) $\mathrm{CH}_{3}{ }^{*} \leftrightarrow \mathrm{CH}_{2}{ }^{*}+\mathrm{H}^{*}$

4) $\mathrm{CH}_{2}{ }^{*} \leftrightarrow \mathrm{CH}^{*}+\mathrm{H}^{*}$

5) $\mathrm{CH}^{*} \leftrightarrow \mathrm{C}^{*}+\mathrm{H}^{*}$

6) $\mathrm{H}^{*}+\mathrm{H}^{*} \leftrightarrow \mathbf{H}_{2}(\mathbf{g}) \quad \mathrm{H}_{2}$ desorption

7) $\mathrm{CO}_{2}(\mathrm{~g}) \leftrightarrow \mathrm{CO}_{2}{ }^{*} \quad \mathrm{CO}_{2}$ adsorption as carbonates

8) $\mathrm{CO}_{2}{ }^{*}+\mathrm{H}^{*} \leftrightarrow \mathrm{COOH}^{*} \quad \mathrm{H}$-assisted $\mathrm{CO}_{2}$ activation

9) $\mathrm{COOH}^{*} \leftrightarrow \mathrm{CO}^{*}+\mathrm{OH}^{*}$

10) $\mathrm{CH}^{*}+\mathrm{O}^{*} \leftrightarrow \mathrm{COH}^{*} \quad$ Oxidation of $\mathrm{CH}_{x}$ fragments 
11) $\mathrm{CHO}^{*} \leftrightarrow \mathrm{CO}^{*}+\mathrm{H}^{*}$

12) $\mathrm{CO}^{*} \leftrightarrow \mathrm{CO}(\mathrm{g})$

Desorption of CO

13) $\mathrm{OH}^{*}+\mathrm{H}^{*} \leftrightarrow \mathrm{H}_{2} \mathrm{O}^{*}$

14) $\mathrm{H}_{2} \mathrm{O}^{*} \leftrightarrow \mathbf{H}_{2} \mathrm{O}(\mathbf{g}) \quad$ Desorption of $\mathrm{H}_{2} \mathrm{O}$

Here, $\left({ }^{*}\right)$ correspond to an adsorption site on the catalyst surface. Among these steps, methane dissociation could be considered the rate-determining steps in the reforming reaction since it is necessary to activate the stable $\mathrm{C}-\mathrm{H}$ bond ${ }^{[28]}$. Figure 7 shows an illustrative representation of the steps than can be tentatively involved in the reaction mechanism of the model biogas reforming. In a first step where the support plays a minor role, the dissociative adsorption of methane on metal $\mathrm{Rh}$ sites produces hydrogen and $\mathrm{CH}_{\mathrm{x}}$ species whereas $\mathrm{CO}_{2}$ is also adsorbed dissociatively on the metallic particles to form $\mathrm{CO}$ and $\mathrm{O}$. Then, this oxygen adsorbed species reacts with $\mathrm{CH}_{\mathrm{x}}$ and leads to formation of $\mathrm{CH}_{x} \mathrm{O}$ species. Finally, the $\mathrm{CH}_{\mathrm{x}} \mathrm{O}$ species then dissociates to form $\mathrm{CO}$ and $\mathrm{H}_{2}$ in a fast step. We can assume that the $\mathrm{CO}_{2}$ dissociation facilitates the $\mathrm{CH}_{4}$ activation by oxygen adsorbed formed in the decomposition of $\mathrm{CO}_{2}$. Besides we believe that the formation of oxygen species provokes a partial oxidation of the Rh metallic particles. As we mentioned above, this oxidation disrupts the Rh-Rh bonds generating the gem-dicarbonyl species and provoking a redispersion of the $\mathrm{Rh}$ particles. Likely this gem-dicarbonyl species are unstable and rapidly are transformed to bridged $\mathrm{CO}$ species. On the other hand, the hydrogen generated in the first step initiates a new bifunctional mechanism in which two types of active centers, basic sites of support and metallic particles, are involved in the reaction pathway where the role of the support is crucial. The $\mathrm{CO}_{2}$ is adsorbed on the basic sites of the support to form carbonates/bicarbonates species that subsequently are transformed to $\mathrm{CO}$ and $\mathrm{H}_{2} \mathrm{O}$ via formation of formate-type intermediates by $\mathrm{H}$-assisted $\mathrm{CO}_{2}$ decomposition. The later process participates in the reaction mechanism through the RWGS reaction and it is obvious that the formation of formate species requires a close vicinity of the carbonate species and the metal adsorbed hydrogen. Therefore, the formation of formate species proceeds mainly at the metalsupport interface although they can migrate to the surface support where they are stably adsorbed and detected by

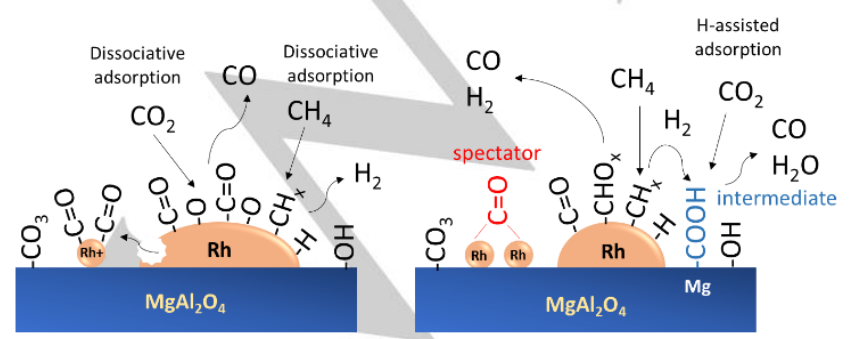

Dissociative adsorption of $\mathrm{CO}_{2}$ and $\mathrm{CH}_{4}$

\section{DRIFTS ${ }^{[29]}$}

Figure 7. Schematic representation of the plausible reaction mechanism for model biogas reforming over $\mathrm{Rh} / \mathrm{MgAl}_{2} \mathrm{O}_{4}$ catalyst.

The majority of the reaction mechanism postulated in the literature for different supported catalysts, except those developed for inert supports, are based on bifunctional pathway. This bifunctional pathway is widely accepted, with the reaction taking place on catalysts with active metal and support having either electrophilic or nucleophilic character. For active metals on inert supports, the metal catalyzes all the surface reactions and is more prone to deactivation due to carbon deposition or sintering ${ }^{[5 a]}$.

\section{Conclusions}

On the basis of in situ transient and steady-state DRIFTS studies, a reaction mechanism focused on the activation of $\mathrm{CO}_{2}$ and $\mathrm{CH}_{4}$ on $\mathrm{MgAl}_{2} \mathrm{O}_{4}$-supported $\mathrm{Rh}$ catalyst was proposed for the model biogas reforming reaction. It was found that dissociative adsorption of $\mathrm{CO}_{2}$ takes place initially and the active oxygen species formed on the metallic sites facilitates the $\mathrm{CH}_{4}$ activation. The hydrogen generated in this first step initiates a new bifunctional mechanism in which $\mathrm{CO}_{2}$ is activated on the basic sites of the support surface via formate intermediate by $\mathrm{H}$ assisted $\mathrm{CO}_{2}$ decomposition. Therefore, $\mathrm{CO}_{2}$ can be transformed into $\mathrm{CO}$ through two pathways: $\mathrm{CO}_{2}$ direct dissociation on metallic sites and $\mathrm{H}$-assisted dissociation on metal-support interface.

\section{Experimental Section}

Rh ( 1 wt.\% nominal) supported over $\mathrm{MgAl}_{2} \mathrm{O}_{4}$ catalyst was prepared by impregnation using the incipient wetness method. For the support synthesis, Y-alumina (Spheralite SCS505) sieved between 100-200 $\mu \mathrm{m}$ was impregnated with an alcoholic solution of $\mathrm{Mg}\left(\mathrm{NO}_{3}\right)_{2} \cdot 6 \mathrm{H}_{2} \mathrm{O}(28 \mathrm{wt}$.\% of $\mathrm{MgO}$ ). It should be mentioned that the theoretical amount of $\mathrm{MgO}$ required to completely transform the alumina into the "ideal" spinel phase is ca. 28 wt. $\%{ }^{[30]}$. Further, the solid was dried overnight at $100 \stackrel{\circ}{ } \mathrm{C}$ and then calcined in air $24 \mathrm{~h}$ at $900{ }^{\circ} \mathrm{C}$. Regarding the active phase impregnation, an aqueous solution of $\mathrm{Rh}\left(\mathrm{NO}_{3}\right)_{3} \cdot 2 \mathrm{H}_{2} \mathrm{O}$ was impregnated over the support and it was dried and calcined in air at $500{ }^{\circ} \mathrm{C}$ for $8 \mathrm{~h}(2$ $\left.{ }^{\circ} \mathrm{C} \mathrm{min}^{-1}\right)$. The elemental composition of the catalyst was determined by ICP analysis. Textural properties, phase structure and morphology of the catalyst were investigated by nitrogen adsorption/desorption isotherms at liquid nitrogen temperature, powder $\mathrm{X}$-ray diffraction and transmission electron microscopy, respectively. Further details on the catalyst characterization are described in the Supporting Information.

The dry reforming activity of the catalyst was measured in a fixed bed continuous-flow reactor working at atmospheric pressure using a commercial Microactivity Reference ${ }^{\circledR}$ equipment. The amount of catalyst used was $50 \mathrm{mg}$ diluted in crushed quartz both sieved in the 100-200 $\mu \mathrm{m}$ range. Prior to reaction, the catalyst was reduced at $750{ }^{\circ} \mathrm{C}$ for $3 \mathrm{~h}$ in a 
$100 \mathrm{~mL} \min ^{-1} \mathrm{H}_{2}\left(50\right.$ vol.\% in $\left.\mathrm{N}_{2}\right)$ stream. The $\mathrm{CH}_{4} / \mathrm{CO}_{2}$ mixture, with molar ratio maintained at 1.5 simulating a model biogas, was passed through the reactor at a total flow rate of $167 \mathrm{ml} \mathrm{min}^{-1}$ (WHSV $=150 \mathrm{~L} \mathrm{~g}^{-1}$ $\mathrm{h}^{-1}$ ) and the reaction temperatures were maintained at $450,550,650$ and $750{ }^{\circ} \mathrm{C}$ in a tubular furnace. A thermocouple was placed into the center of the catalyst bed to record the reaction temperature and to control the furnace. Gas products were analyzed on line using a microGC (Varian 4900) equipped with Porapak $Q$ and MS-5A columns. The conversions of $\mathrm{CH}_{4}$ and $\mathrm{CO}_{2}$ were calculated based on the difference between the input and output of $\mathrm{CH}_{4}$ and $\mathrm{CO}_{2}$, respectively.

In-situ DRIFTS measurements were carried out using a high temperature environmental reaction chamber supported in a Praying Mantis (Harrick) DRIFTS optical system with ZnSe windows. The spectra were collected using a Thermo Nicolet Nexus FT-IR spectrometer equipped with a liquid nitrogen cooled MCT detector at $4 \mathrm{~cm}^{-1}$ resolution and average of 64 scans. The whole optical path was purged with $\mathrm{CO}_{2-}$ and $\mathrm{H}_{2} \mathrm{O}$-free nitrogen. About $50 \mathrm{mg}$ of catalyst finely ground was loaded in the cell for each measurement. The gases pass through the catalyst packed-bed, mimicking the plug-flow condition of the reaction. Different mixtures of gases could be introduced into the cell, and the gas flows were controlled by mass-flow controllers from AALBORG appropriately calibrated. All the valves, connexions and pipelines of the reaction system were heated at $100{ }^{\circ} \mathrm{C}$ to prevent the water condensation produced during the reaction. Prior to the measurements, the catalyst was activated in situ at $750{ }^{\circ} \mathrm{C}$ in $50 \% \mathrm{H}_{2} / \mathrm{N}_{2}$ in a total flow rate of $50 \mathrm{~mL}$ $\min ^{-1}$.

For the transient experiments, the different mixtures at a total flow rate of $50 \mathrm{~mL} \mathrm{~min}^{-1}\left(10 \% \mathrm{CO}_{2}\right.$ diluted in $\mathrm{N}_{2}, 15 \% \mathrm{CH}_{4}$ diluted in $\mathrm{N}_{2}, 40 \%$ $\mathrm{H}_{2}+10 \% \mathrm{CO}_{2}$ diluted in $\mathrm{N}_{2}$ ) were switched and introduced into the IR cell under isothermal conditions at $600^{\circ} \mathrm{C}$ every $560 \mathrm{~s}$. A four-way valve was installed to allow us to switch between two gas mixtures. The experiment of steady-state was performed feeding into the IR cell a mixture of $15 \%$ $\mathrm{CH}_{4}$ and $10 \% \mathrm{CO}_{2}$ in nitrogen balance for a total flow rate of $50 \mathrm{~mL} \mathrm{~min} 1$ The temperature range used varies from 450 to $750{ }^{\circ} \mathrm{C}$ with stepwise at $50^{\circ} \mathrm{C}$ intervals and remaining at each temperature for $30 \mathrm{~min}$ in order to obtain steady-state conditions. The concentration of $\mathrm{CO}_{2}$ was monitored by time-resolved analysis using a VAISALA $\mathrm{CO}_{2}$ measurement meter. The concentration of $\mathrm{CH}_{4}$ was estimated by integration of the band area of $\mathrm{V}_{\mathrm{as}}(\mathrm{C}-\mathrm{H})$ attributed to gas phase methane $\left(3015 \mathrm{~cm}^{-1}\right)$. A previous calibration by flowing $\mathrm{CH}_{4} / \mathrm{N}_{2}$ mixtures over $\alpha-\mathrm{Al}_{2} \mathrm{O}_{3}$ at different temperatures was performed to obtain the relationship between the band area of $\mathrm{V}_{\text {as }}(\mathrm{C}-\mathrm{H})$ and the partial pressure of methane inside the cell. In the temperature range used, no reaction between methane and $\alpha-\mathrm{Al}_{2} \mathrm{O}_{3}$ was observed, although the thermal effect must be considered. As temperature increases, the intensity of gaseous compounds DRIFTS signal decrease. With this kind of calibration, absorption coefficients can be estimated, and product quantitative analysis can be made in catalytic tests. This one, for instance, has been used in $\mathrm{CO}$ and $\mathrm{CO}_{2}$ methanation reactions over $\mathrm{Rh}$-supported catalysts ${ }^{[31]}$.

\section{Acknowledgements}

Financial support for this work has been obtained from the Spanish Ministerio de Economía y Competitividad (MINECO) (ENE2013-47880-C3-2-R and ENE2015-66975-C3-2-R) and from Junta de Andalucía (TEP-8196). Victoria Garcilaso ackowledges MINECO by their FPI fellowship (BES-2013062806)
Keywords: Biogas reforming $\bullet$ Reaction mechanism $\bullet$ In situ transient DRIFTS

[1] S. Perathoner, G. Centi, ChemSusChem 2014, 7, 1274-1282.

[2] S. Zinoviev, F. Müller-Langer, P. Das, N. Bertero, P. Fornasiero, M. Kaltschmitt, G. Centi, S. Miertus, ChemSusChem 2010, 3, 1106-1133.

[3] aV. P. Rathod, J. Shete, P. V. Bhale, Int. J. Hydrogen Energy 2016, 41 132-138; bP. Djinović, I. G. O. Črnivec, A. Pintar, Catal. Today 2015 253, 155-162; cV. Chiodo, A. Galvagno, A. Lanzini, D. Papurello, F. Urbani, M. Santarelli, S. Freni, Energy Conv. Manag. 2015, 98, 252-258.

[4] A. Vita, L. Pino, F. Cipitì, M. Laganà, V. Recupero, Fuel Process. Technol. 2014, 127, 47-58.

[5] aD. Pakhare, J. Spivey, Chem. Soc. Rev. 2014, 43, 7813-7837; bM. C J. Bradford, M. A. Vannice, Catal. Rev. Sci. Eng. 1999, 41, 1-42; cC. Papadopoulou, H. Matralis, X. Verykios, in Catalysis for Alternative Energy Generation (Eds.: L. Guczi, A. Erdôhelyi), Springer New York, New York, NY, 2012, pp. 57-127; dB. C. Enger, R. Lødeng, A. Holmen, Int. J. Hydrogen Energy 2012, 37, 10418-10424.

[6] aY. H. Hu, E. Ruckenstein, in Adv. Catal., Vol. Volume 48, Academic Press, 2004, pp. 297-345; bJ. R. Rostrup-Nielsen, J. H. B. Hansen, J. Catal. 1993, 144, 38-49; cJ. Wei, E. Iglesia, J. Phys. Chem. B 2004 108, 4094-4103.

[7] aJ. Wei, E. Iglesia, J. Catal. 2004, 225, 116-127; bH. Y. Wang, E. Ruckenstein, Appl. Catal. A Gen. 2000, 204, 143-152; cA. Erdöhelyi, J. Cserenyi, F. Solymosi, J. Catal. 1993, 141, 287-299.

[8] L. Zhang, Q. Zhang, Y. Liu, Y. Zhang, Appl. Surf. Sci. 2016, 389, 25-33.

[9] F. Polo-Garzón, M. He, D. A. Bruce, J. Catal. 2016, 333, 59-70.

[10] F. Polo-Garzón, D. Pakhare, J. J. Spivey, D. A. Bruce, ACS Catal. 2016 6, 3826-3833

[11] K. Parkhomenko, A. Tyunyaev, L. M. Martinez Tejada, D. Komissarenko, A. Dedov, A. Loktev, I. Moiseev, A.-C. Roger, Catal. Today 2012, 189, 129-135.

[12] N. D. Charisiou, G. Siakavelas, K. N. Papageridis, A. Baklavaridis, L. Tzounis, D. G. Avraam, M. A. Goula, J. Natural Gas Sci. Eng. 2016, 31, 164-183.

[13] M. K. Nikoo, N. A. S. Amin, Fuel Process. Technol. 2011, 92, 678-691.

[14] F. Solymosi, J. Mol. Catal. 1991, 65, 337-358.

[15] aC. Morterra, G. Ghiotti, F. Boccuzi, S. Coluccia, J. Catal. 1978, 51, 299-313; bF. Solymosi, A. Erdöhelyi, M. Kocsis, J. Catal. 1980, 65, 428-436; cY.-G. Chen, K. Tomishige, K. Yokoyama, K. Fujimoto, J. Catal. 1999, 184, 479-490; dD. Li, R. Li, M. Lu, X. Lin, Y. Zhan, L. Jiang, Appl. Catal. B Environ. 2017, 200, 566-577; eJ. I. Di Cosimo, V. K. Díez, M. Xu, E. Iglesia, C. R. Apesteguía, J. Catal. 1998, 178, 499-510.

[16] M. A. Al-Daous, A. A. Manda, H. Hattori, J. Mol. Catal. A Chem. 2012 363-364, 512-520.

[17] aC. M. Carbonell, C. O. Areán, Vib. Spectrosc. 1996, 12, 103-107; bM. Cavers, J. M. Davidson, I. R. Harkness, L. V. C. Rees, G. S. McDougall, J. Catal. 1999, 188, 426-430.

[18] S. Trautmann, M. Baerns, J. Catal. 1994, 150, 335-344.

[19] F. Solymosi, M. Pasztor, J Phys. Chem. 1985, 89, 4789-4793.

[20] P. Malet, J. J. Benitez, M. J. Capitan, M. A. Centeno, I. Carrizosa, J. A. Odriozola, Catal. Lett. 1993, 18, 81-97.

[21] aC. M. Carbonell, C. O. Areán, Vibr. Spectrosc. 1996, 12, 103-107; bE. Finocchio, G. Busca, P. Forzatti, G. Groppi, A. Beretta, Langmuir 2007 23, 10419-10428.

[22] M. Boudart, Chem. Rev. 1995, 95, 661-666

[23] T. R. Reina, S. Ivanova, J. J. Delgado, I. Ivanov, V. Idakiev, T. Tabakova, M. A. Centeno, J. A. Odriozola, ChemCatChem 2014, 6 1401-1409.

[24] M. Polisset, University of Paris VI 1990

[25] J. Zhang, H. Wang, A. K. Dalai, Ind. Eng. Chem. Res. 2009, 48, 677684.

[26] K. Nagaoka, K. Seshan, J. A. Lercher, K.-i. Aika, Catal. Lett. 2000, 70, 109-116. 
[27] Y. Kathiraser, U. Oemar, E. T. Saw, Z. Li, S. Kawi, Chem. Eng. J. 2015, 278, 62-78.

[28] A. C. Luntz, J. Harris, Surf. Sci. 1991, 258, 397-426.

[29] D. Heyl, U. Rodemerck, U. Bentrup, ACS Catal. 2016, 6, 6275-6284.
[30] A. Penkova, L. Bobadilla, S. Ivanova, M. I. Domínguez, F. RomeroSarria, A. C. Roger, M. A. Centeno, J. A. Odriozola, Appl. Catal. A Gen. 2011, 392, 184-191.

[31] J. J. Benítez, I. Carrizosa, J. A. Odriozola, Appl. Spectrosc. 1993, 47, 1760-1766. 


\section{FULL PAPER}

Understanding the mechanism: The production of syngas from biogas represents an attractive approach for reducing greenhouse emissions. We contribute to gain a better understanding of the reaction mechanism in the biogas reforming for developing more economic and efficient catalysts.

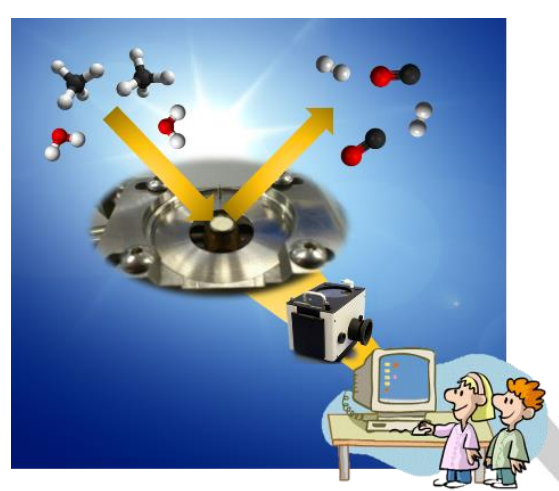

Luis F. Bobadilla, *Victoria Garcilaso, Miguel A. Centeno and José $A$.

Odriozola*

Page No. - Page No.

Monitoring the reaction mechanism in model biogas reforming by in situ transient and steady-state DRIFTS measurements 